\title{
The Preparation and Properties of $\beta$-Glucuronidase
}

\author{
1. THE FRACTIONATION OF BUFFERED WATER HOMOGENATES
}

\author{
BY LYNDA M. H. KERR AND G. A. LEVVY \\ Rowett Research Institute, Bucksburn, Aberdeenshire
}

(Received 17 July 1950)

For the assay of $\beta$-glucuronidase in animal tissues, it has been customary to prepare acid extracts from the water homogenates. Thus Talalay, Fishman \& Huggins (1946) bring the homogenate to $\mathrm{pH} 5$ with acetic acid, and incubate for $30 \mathrm{~min}$. before removing insoluble material on the centrifuge. Kerr, Graham \& Levvy (1948) follow a similar procedure, but adjust the $\mathrm{pH}$ to $5 \cdot 2$ with citrate buffer. Incubation at acid pH makes precipitated material more compact, but should obviously be kept as brief as possible if the final glucuronidase activity of the extract is to be taken as representative of that of the fresh tissue.

Becker \& Friedenwald (1949) found that part of the glucuronidase activity of rat liver is precipitated at acid pH. This finding, which has recently been confirmed with mouse liver by Morrow, Greenspan \& Carroll (1949), introduces possibilities of complications in the enzyme assay, which must be taken into account in comparing results obtained by different workers. The possibility had also to be considered that in our studies of the enzyme in varying states of tissue proliferation (Levvy, Kerr \& Campbell, 1948; Kerr, Campbell \& Levvy, 1949, 1950) we were dealing with changes in only one fraction of the total activity, or with a transfer of activity from one fraction to another.

A study has been made of various factors entering into the preparation of tissue extracts which influence the results obtained in glucuronidase assay. The findings cast some light on the physical state of the enzyme in the cell.

\section{EXPERIMENTAL AND RESULTS}

\section{General methods}

Preparation of the enzyme. The tissue, usually mouse liver, was ground with water for 1 min. in a glass homogenizer. Water and buffer solution were added to the homogenate so that the final preparation was $0.1 \mathrm{~N}$ with respect to the buffer and contained $1 \mathrm{~g}$. of moist tissue in $10 \mathrm{ml}$. (' $10 \%$ preparation'). The $\mathrm{pH}$ of the preparation was checked with the glass electrode. Centrifuging was done on the M.S.E. Minor (Measuring and Scientific Equipment Ltd., London, S.W. 1) at about $1500 \mathrm{~g}$ for $15 \mathrm{~min}$. Sedimented material was washed on the centrifuge with one-tenth of the original volume of $0.1 \mathrm{~N}-\mathrm{buffer}$, and this was added to the supernatant. For assay, the sediment was resuspended in $0.1 \mathrm{~N}$-buffer with the aid of the glass homogenizer.
Enzyme assay. This was done by a modification of the method of Talalay et al. (1946), using phenolphthalein glucuronide as substrate. Throughout the assay, the same type of buffer was used as in the preparation of the enzyme. All enzyme preparations, totals or fractions were diluted with $0.1 \mathrm{v}$-buffer to a final volume of $40 \mathrm{ml}$./g. of tissue (' $2.5 \%$ preparation'), with $\mathrm{pH}$ adjustment if necessary to 5.2. To $0.5 \mathrm{ml}$. of this preparation were added $3 \mathrm{ml}$. of $0.1 \mathrm{~N}$-buffer,

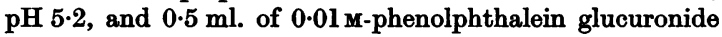
solution at the same $\mathrm{pH}$. After incubation at $37^{\circ}$ for $1 \mathrm{hr}$.,

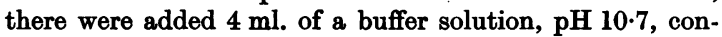
taining glycine $(0.4 \mathrm{M}), \mathrm{NaCl}(0.2 \mathrm{M})$ and $\mathrm{Na}_{2} \mathrm{CO}_{3}(0.25 \mathrm{M})$. Karunairatnam (private communication) has found that addition of $\mathrm{Na}_{8} \mathrm{CO}_{8}$ increases the efficiency of the glycine buffer. The mixture was centrifuged at $1500 \mathrm{~g}$ for $15 \mathrm{~min}$., and the intensity of the red colour in the supernatant read with a Spekker photoelectric absorptiometer, using Ilford no. 605 yellow-green filter. Results are quoted as glucuronidase units (G.J.)/g. moist tissue, 1 G.J. liberating $1 \mu \mathrm{g}$. of phenolphthalein under the conditions described.

\section{Fractionation of buffered homogenates}

Table 1 shows the fractionation of the enzyme in an unincubated mouse-liver homogenate which was obtained when it was centrifuged after $\mathrm{pH}$ adjustment to $5 \cdot 2$ with acetate or citrate buffer. Sufficient animals were used in each experiment to keep the tissue concentration in the homogenate $10 \%$. In many of the experiments, the preparation was kept ice-cold on the homogenizer and centrifuge, but omission of this precaution did not influence the fractionation. Homogenizing straight away in $0.1 \mathrm{~N}$-buffer had no effect on the fractionation. Measurements of total activity in the unfractionated homogenate agreed with the sums of the two fractions.

It can be seen that in either acetate or citrate buffer just over $40 \%$ of the enzyme activity in normal adult liver was precipitated with the cell debris. The activity figure in citrate was always about $10 \%$ lower than the corresponding acetate figure, showing slight inhibition of glucuronidase by the former buffer (see Oshima, 1936; Mills \& Paul, 1949). The glucuronidase activities of infant liver and of adult liver regenerating after partial hepatectomy have been shown to be high in comparison with normal adult values (Levvy et al. 1948). It would now appear that the differences in enzyme activity are confined to the soluble fraction, as shown 
in Table 1. The percentage increase in activity observed on passing from a normal adult to an infant or regenerating tissue will thus be smaller if the assay figure includes the invariable activity of the debris.

Bringing the $\mathrm{pH}$ of a homogenate to 5.2 with hydrochloric acid, or by the addition of other buffers than acetate or citrate (phosphate, propionate, lactate, succinate or phthalate) led to a similar fractionation to that shown in Table 1.

When unbuffered homogenates ( $\mathrm{pH}$ about 6.3) were centrifuged at $1500 \mathrm{~g}$, the small precipitate obtained had no glucuronidase activity. Subsequent buffering of the supernatant to $5 \cdot 2$ with acetate then gave rise to the usual fractionation of the enzyme. As shown in the next paper in this series (Walker \& Levvy, 1950), identical fractionation of the enzyme in such a supernatant can be obtained without prior $\mathrm{pH}$ adjustment on the high-speed centrifuge at
$20,000 \mathrm{~g}$. Microscopic study reveals the active precipitate to be granular in character. Addition of acetate to suspensions leads to clumping of the granules and easier sedimentation. In fact, slow sedimentation occurs in acetate under the action of gravity alone.

\section{Effect of varying the $\mathrm{pH}$ and concentration of the buffer}

Table 2 shows the effect of varying the $\mathrm{pH}$ of acetate or citrate buffer $(0 \cdot 1 \mathrm{~N})$ on the fractionation of the enzyme in mouse liver. With acetate buffer, the partition of the enzyme between debris and supernatant did not change appreciably over the $\mathrm{pH}$ range $5 \cdot 0-5 \cdot 6$. With citrate buffer, on the other hand, the fraction of the total enzyme activity which was precipitated decreased when the $\mathrm{pH}$ was raised beyond 5.2. In the higher pH range, the enzyme in the debris proved to be extractable on washing with

\section{Table 1. Fractionation of mouse-liver glucuronidase in buffered homogenates, pH $\mathbf{5 \cdot 2}$}

(Substrate, phenolphthalein glucuronide. Values shown as mean \pm s.E., followed in parentheses by the number of experiments. G.U., glucuronidase units: for definition see text.)

Glucuronidase activity (G.U./g. tissue)

\begin{tabular}{|c|c|c|c|c|}
\hline \multirow[b]{2}{*}{ Description } & \multicolumn{2}{|c|}{ Acetate buffer } & \multicolumn{2}{|c|}{ Citrate buffer } \\
\hline & Supernatant & Debris* & Supernatant & Debris* \\
\hline $\begin{array}{l}\text { Normal adult } \\
\text { Infant ( } 2-8 \text { days old) } \\
\text { Adult, } 4 \text { days after partial hepatectomy }\end{array}$ & $\begin{array}{l}1550 \pm 130(14) \\
4190 \pm 210(7) \\
2880 \pm 100(6)\end{array}$ & $\begin{array}{l}1140 \pm 70(14) \\
1110 \pm 100(7) \\
1110 \pm 30(6)\end{array}$ & $\begin{array}{l}1390 \pm 120(14) \\
3960 \pm 340(6) \\
2670 \pm 40(6)\end{array}$ & $\begin{array}{l}1030 \pm 70(14) \\
1030 \pm 100(6) \\
1020 \pm 20(6)\end{array}$ \\
\hline
\end{tabular}

Table 2. Effect of $\mathrm{pH}$ of the buffer on the fractionation of mouse-liver homogenate

(Buffer concentration 0.1 w. Substrate, phenolphthalein glucuronide. Results shown as \% of initial homogenate activity.)

\begin{tabular}{|c|c|c|c|c|c|c|}
\hline \multirow[b]{2}{*}{ pH } & \multicolumn{3}{|c|}{ Acetate buffer } & \multicolumn{3}{|c|}{ Citrate buffer } \\
\hline & $\begin{array}{c}\text { Initial } \\
\text { supernatant }\end{array}$ & $\begin{array}{l}\text { Initial } \\
\text { debris* }\end{array}$ & $\begin{array}{c}\text { Debris } \\
\text { after } \\
\text { washing } \dagger\end{array}$ & $\underset{\text { supernatant }}{\text { Initial }}$ & $\underset{\text { debris* }}{\text { Initial }}$ & $\begin{array}{c}\text { Debris } \\
\text { after } \\
\text { washing } \dagger\end{array}$ \\
\hline $\begin{array}{l}5 \cdot 0 \\
5 \cdot 2 \\
5 \cdot 4 \\
5 \cdot 6\end{array}$ & $\begin{array}{l}61 \\
58 \\
61 \\
62\end{array}$ & $\begin{array}{l}39 \\
45 \\
42 \\
44\end{array}$ & $\begin{array}{l}37 \\
43 \\
43 \\
42\end{array}$ & $\begin{array}{l}62 \\
62 \\
66 \\
89\end{array}$ & $\begin{array}{l}42 \\
44 \\
39 \\
20\end{array}$ & $\begin{array}{r}39 \\
43 \\
23 \\
9\end{array}$ \\
\hline
\end{tabular}

* Washed once on the centrifuge. $\quad+$ Additional three washings on centrifuge.

Table 3. Effect of varying the concentration of the buffer (pH 5.2) on the fractionation of mouse-liver homogenate

(Substrate, phenolphthalein glucuronide. Results shown as \% of initial homogenate activity.)

$\begin{array}{cccccccc}\begin{array}{c}\text { Buffer } \\ \text { concentration } \\ (N)\end{array} & \begin{array}{c}\text { Initial } \\ \text { supernatant }\end{array} & \begin{array}{c}\text { Initial } \\ \text { debris }\end{array} & \begin{array}{c}\text { Debris } \\ \text { after } \\ \text { washing* }\end{array} & \overbrace{\begin{array}{c}\text { Initial } \\ \text { supernatant }\end{array}}^{\text {Acetate buffer }} & \begin{array}{c}\text { Initial } \\ \text { debris }\end{array} & \begin{array}{c}\text { Debris } \\ \text { after } \\ \text { washing* }\end{array} \\ 0.5 & 61 & 39 & 38 & 78 & 23 & 13 \\ 0.25 & 61 & 41 & 41 & 68 & 34 & 31 \\ 0.1 & 61 & 39 & 38 & 56 & 47 & 43 \\ 0.05 & 62 & 39 & 38 & 53 & 45 & 40 \\ 0.025 & 62 & 41 & 38 & 54 & 45 & 40\end{array}$

* Washed thrice on centrifuge. 
citrate, but not with acetate. Further experiments showed that extraction of the granular enzyme with citrate buffer, $\mathrm{pH}$ 5.4-5.6, followed the same course whether the initial precipitation was done in acetate or citrate. Of other buffers mentioned in the preceding section, the one which most closely resembled citrate for extraction purposes was phosphate.

From Table 3 it can be seen that as the concentration of citrate buffer increased at constant $\mathrm{pH}(5 \cdot 2)$ so did its efficiency in extracting the debris enzyme. Varying the acetate concentration had no effect of any kind on the fractionation.

\section{Changes in the partition of the enzyme during incubation of homogenates}

The water homogenate was buffered to $\mathrm{pH} 5 \cdot 2$ and incubated at $37^{\circ}$. At varying periods, samples were withdrawn for glucuronidase assay, with and without prior fractionation on the centrifuge.

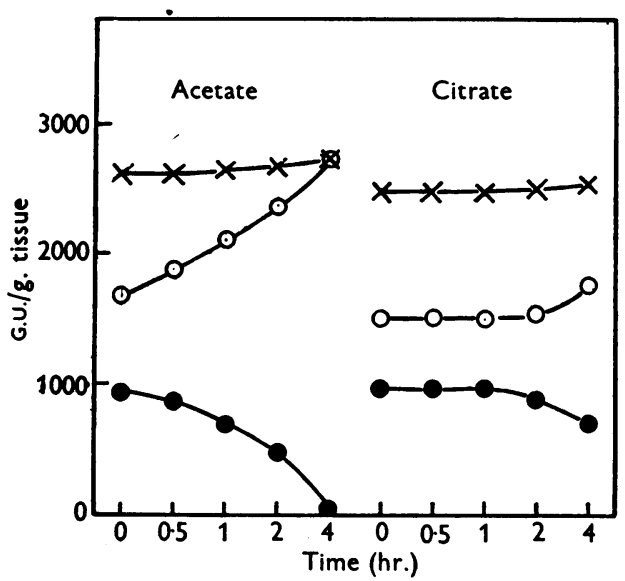

Fig. 1. Fractionation of homogenates of normal adult mouse liver after varying periods of incubation in acetate or citrate buffer, pH 5.2. Substrate, phenolphthalein glucuronide. $x-x$, Total homogenate; -0 , debris (washed thrice on centrifuge); $\mathrm{O}-\mathrm{O}$, supernatant. (For definition of G.v. and details of assay procedure see text.)

Figs. 1-3 show results obtained with normal adult liver, infant liver, and liver regenerating after partial hepatectomy respectively. In acetate buffer, there was a progressive loss of enzyme activity from the granular material to the supernatant, with little change in the overall activity of the homogenate. This process was complete in about $4 \mathrm{hr}$. Figures for glucuronidase activity based on acetate extracts of the tissue thus depend entirely upon the duration of the incubation before removal of debris. Unless the time factor is strictly controlled, changes in the activity of the soluble enzyme in vivo may be obscured. With citrate buffer, any loss of enzyme from the debris to the supernatent was much less marked.
A short period of incubation in this buffer can be seen to have little effect on the assay figure for the soluble enzyme fraction.

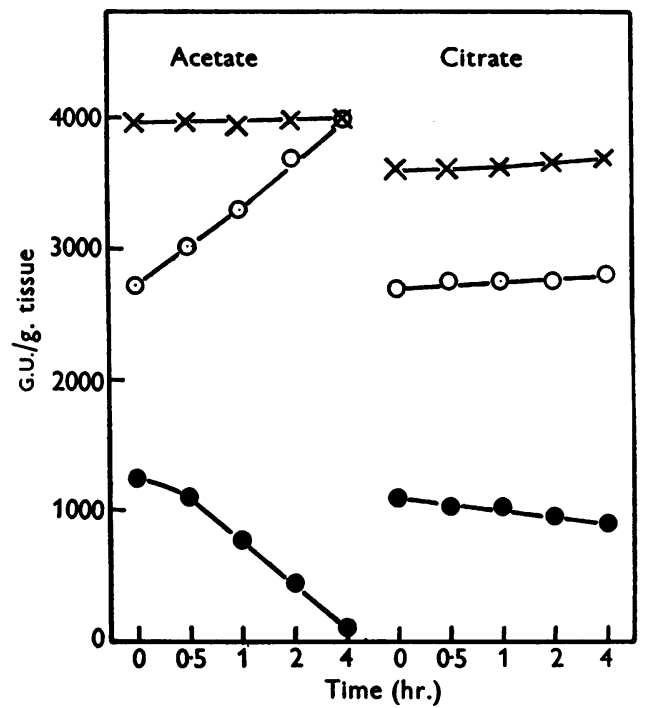

Fig. 2. Fractionation of homogenates of 5 day old mouse liver after varying periods of incubation in acetate or citrate buffer, pH 5.2. Substrate, phenolphthalein glucuronide. $x-x$, Total homogenate; -0 , debris (washed thrice on centrifuge); $\mathrm{O}-\mathrm{O}$, supernatant.

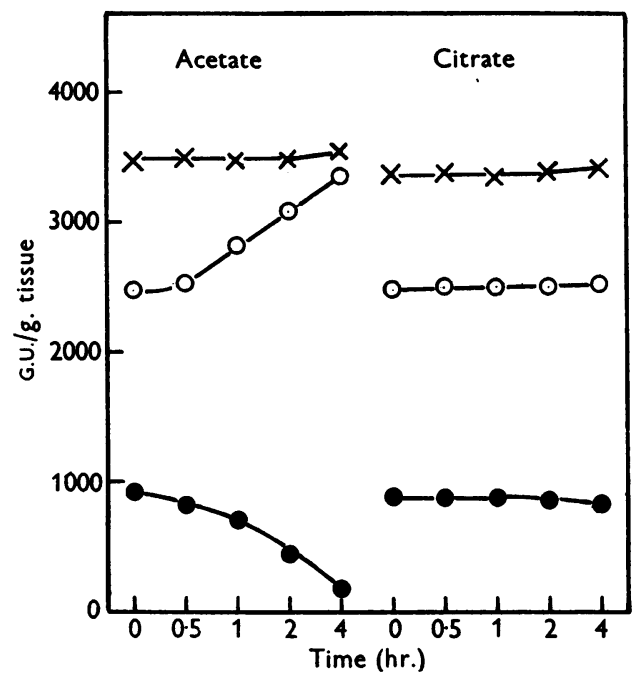

Fig. 3. Fractionation of homogenates of adult mouse liver 4 days after partial hepatectomy. Homogenate incubated for varying periods in acetate or citrate buffer, pH 5.2. Substrate, phenolphthalein glucuronide. $x-x$, Total homogenate; - , debris (washed thrice on centrifuge); $\mathrm{O}-\mathrm{O}$, supernatant.

Supernatants separated prior to incubation showed no change in activity after incubation for 
$4 \mathrm{hr}$. in acetate buffer, pH 5.2. Longer periods of incubation sometimes resulted in partial inactivation. Fractionation of suspensions of washed granular material incubated at $37^{\circ}$ revealed a fall in debris activity exactly as illustrated in Figs. 1-3, with the formation of equivalent amounts of soluble enzyme. Citrate again inhibited the transfer of activity from the debris to the supernatant.

\section{Effect of varying $\mathrm{pH}$ on the liberation of enzyme from the debris}

A study was made of the effect of varying the $\mathrm{pH}$ on the rate of liberation of soluble enzyme from the granules in acetate buffer at $37^{\circ}$. Washed mouse-liver

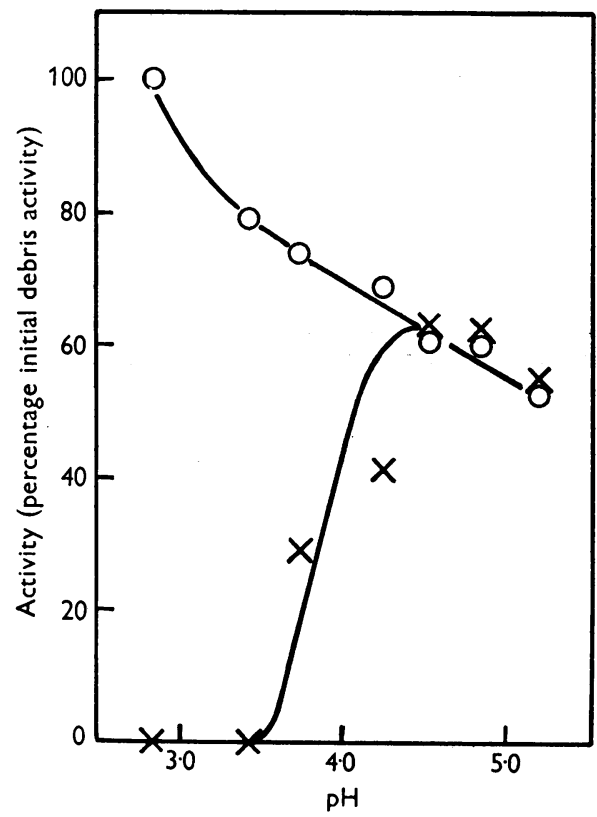

Fig. 4. Effect of varying $\mathrm{pH}$ on the rate of liberation of enzyme from washed mouse-liver debris in acetate buffer. Incubation for $1 \mathrm{hr}$., followed by separation and assay (phenolphthalein glucuronide) at pH 5.2. Results expressed as percentages of unincubated debris activity. $\mathrm{O}-\mathrm{O}$, Loss in debris activity; $\times-\times$, supernatant activity.

debris, separated at $\mathbf{p H ~} 5 \cdot 2$, was suspended in buffer solutions of various $\mathrm{pH}$ values and incubated for $1 \mathrm{hr}$. After bringing the $\mathrm{pH}$ back to 5·2, the preparation was centrifuged and measurements made of the glucuronidase activity of the two fractions in acetate buffer. Fig. 4 shows the loss in debris activity and the gain in supernatant activity, both expressed as percentages of the initial debris value. As the $\mathrm{pH}$ fell from $5 \cdot 2$ to $4 \cdot 5$, there was a slight increase in the rate of transfer of enzyme from debris to supernatant. Below pH 4.5, enzyme inactivation became marked, and the loss in debris activity was no longer balanced by a gain in the supernatant. At $\mathrm{pH} \mathrm{3.4,} \mathrm{incubation} \mathrm{for} 1 \mathrm{hr}$. caused a fall of about $80 \%$ in the debris activity, and completely inactivated any enzyme which had gone into solution.

Preparations of the soluble enzyme from unincubated homogenates were incubated for $1 \mathrm{hr}$. at various $\mathrm{pH}$ values in acetate buffer, with final assay after $\mathrm{pH}$ adjustment to 5.2. There was no fall in activity after incubation at $\mathbf{p H} 4 \cdot 5-5 \cdot 2$. Below this, inactivation was observed, reaching $100 \%$ at $\mathrm{pH} 3 \cdot 4$.

These experiments suggest that all the soluble mouse-liver glucuronidase is inactive in an assay following a preliminary incubation for $1 \mathrm{hr}$. in acetate buffer at $\mathrm{pH} \mathrm{3.4}$. Mills \& Paul (1949) and Mills, Paul \& Smith (1949) have, however, reported the presence in tissue extracts of a glucuronidase with a pH optimum at 3.4. This enzyme was at first claimed to be specific for the hydrolysis of phenol glucuronide, but has since been found (Mills, private communication) to hydrolyse phenolphthalein glucuronide, also with optimal activity at $\mathrm{pH} \mathrm{3.4.}$ Experiments along the lines of those described above, with final assay (phenolphthalein glucuronide in acetate buffer) at pH 3.4 instead of 5.2, showed no activity whatsoever in any fraction after preliminary incubation for $1 \mathrm{hr}$. at $\mathrm{pH} \mathrm{3.4}$. This was also true for unfractionated homogenates put through the same procedure. These findings suggest that, if the enzyme with optimal activity at $\mathrm{pH} 3.4$ is present in mouse liver, it is very unstable at the optimum $\mathrm{pH}$, in crude preparations at least.

\section{Effect of varying the tissue concentration on the liberation of debris enzyme and in the final assay}

As shown in Fig. 5, the rate of liberation of glucuronidase from the granular material during the incubation of a mouse-liver homogenate at $37^{\circ}$ in acetate buffer, $\mathrm{pH} 5 \cdot 2$, was unaffected by the tissue concentration. Parallel experiments were done with the preparation diluted to 10 and to $40 \%$. At the last stage before incubation with substrate all preparations were brought to $2.5 \%$.

In the final incubation with substrate the activity figures for preparations containing insoluble enzyme were markedly influenced by variations in the concentration of tissue constituents. This is illustrated in Table 4. When $0.5 \mathrm{ml}$. of an unincubated homogenate in which the tissue concentration was $40 \%$ was taken straight for assay in acetate, the final activity figure was only about half that obtained when the preparation was first diluted to $2.5 \%$. Low values for the activity were still obtained after fractionation of the $40 \%$ preparation, particularly in the case of the insoluble fraction. Since, however, each fraction was brought to the same volume as that of the homogenate, there was a dilution of the tissue 
at this stage, resulting in an apparent increase in the overall activity of the $40 \%$ preparation after fractionation.

When the debris enzyme was completely converted to the soluble form by preliminary incubation for $4 \mathrm{hr}$., variations in the tissue concentration no longer affected the rate of hydrolysis of the substrate. The $40 \%$ preparation thus appeared to show an increase in total activity during the incubation.

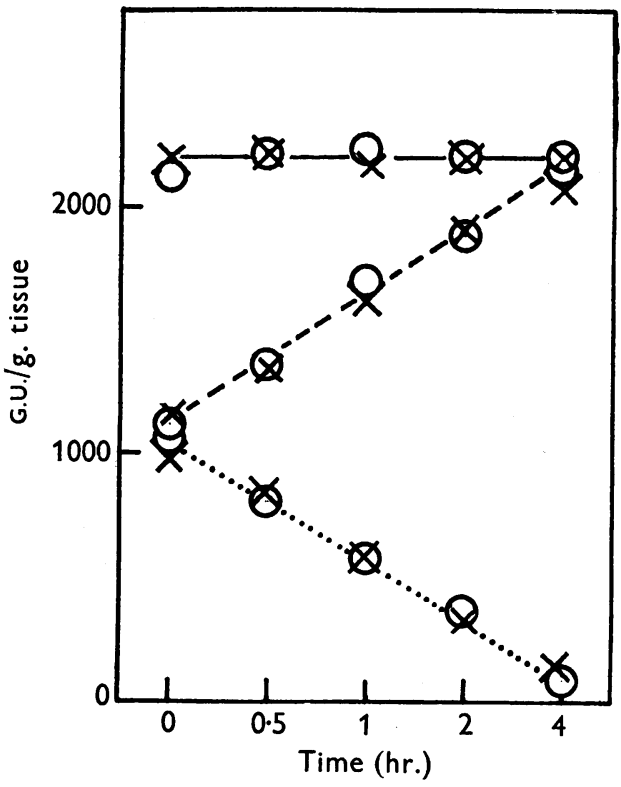

Fig. 5. Effect of varying the tissue concentration on the rate of liberation of enzyme from mouse-liver debris in acetate buffer, pH 5·2. Substrate, phenolphthalein glucuronide. $\times, 40 \%$ homogenate; $O, 10 \%$ homogenate. -, Total; ---, supernatant; ....., debris.

The tissue concentration factor makes the glucuronidase assay procedure of Kerr et al. (1948) inapplicable for present purposes, since the final enzyme concentration required in the incubation with phenol glucuronide corresponds to that resulting from the use of a $40 \%$ preparation in the assay with phenolphthalein glucuronide. On this account, a great many experiments carried out in the early stages of this work have had to be discarded. The apparent changes in the activities of unfractionated mouse-liver homogenates during incubation in acetate buffer, as measured with phenol glucuronide, are shown in Fig. 6. The homogenates were $10 \%$ at

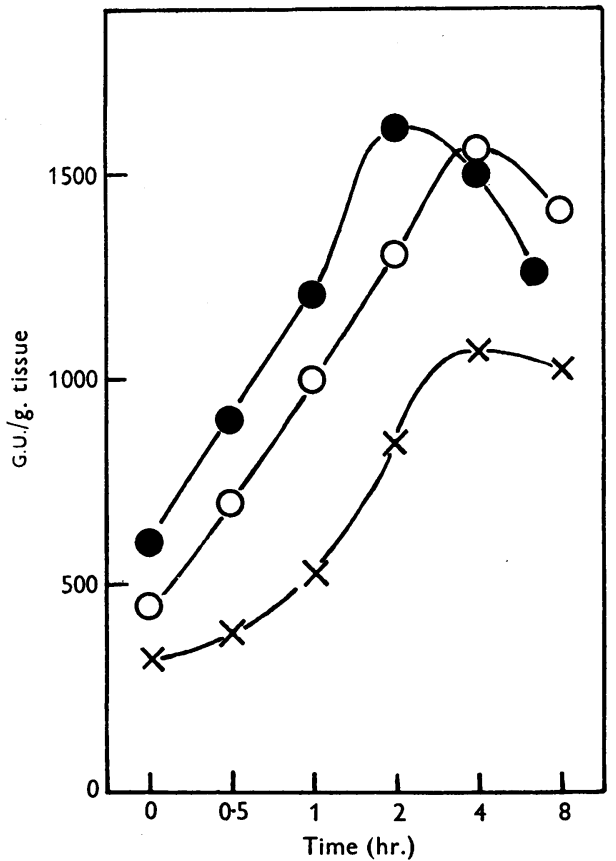

Fig. 6. Apparent change in the total activities of $10 \%$ mouse-liver homogenates during incubation at $37^{\circ}$ in acetate buffer, pH 5.2. Substrate, phenol glucuronide in acetate buffer. $x-\times$, Normal adult; $-0,4$ day old infants; $\mathrm{O}-\mathrm{O}$, adult, 4 days after partial hepatectomy. See Kerr et al. (1948) for definition of G.J. and details of assay procedure.

this stage. The addition of buffered substrate (Kerr et al. 1948) resulted in a twofold dilution (cf. the eightfold dilution in the assay with phenolphthalein glucuronide). Fig. 6 shows the effects of heat inactivation very clearly.

It should perhaps be pointed out that our studies of glucuronidase in tissues in varying states of

Table 4. Effect of varying the tissue concentration during the incubation with substrate

(Acetate buffer, pH 5·2. Substrate, phenolphthalein glucuronide. Normal mouse liver. G.U., glucuronidase units; for definition see text.)

Glucuronidase activity

$$
\text { (G.U./g. tissue) }
$$

Final concentration of tissue

(g. moist tissue $/ 100 \mathrm{ml}$.)

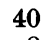

8

$2 \cdot 5$

\begin{tabular}{ccc}
\multicolumn{3}{c}{ No preliminary incubation } \\
\hline Total & Supernatant & Debris* \\
1100 & 815 & 628 \\
2080 & 1100 & 990 \\
2040 & 1080 & 1050
\end{tabular}

* Washed thrice on centrifuge
Preliminary incubation for $4 \mathrm{hr}$.

$\begin{array}{ccc}\text { Total } & \text { Supernatant } & \text { Debris* } \\ 1920 & 1930 & 0 \\ 2110 & 2060 & 0 \\ 2020 & 1940 & 0\end{array}$

$\mathbf{0}$ 
proliferation, referred to in the Introduction, were carried out with preparations of the soluble enzyme fraction, after partial purification by precipitation with ammonium sulphate.

\section{pH-activity curve for the insoluble enzyme}

The pH-activity curve for the hydrolysis of phenol glucuronide by preparations of soluble mouseliver glucuronidase has two peaks in citrate buffer, one at $\mathrm{pH} 4.5$ and the other at pH 5.2 (Kerr et al. 1948). Separation into two fractions corresponding to the two optima can be achieved by making the preparation $38.5 \%$ saturated with ammonium sulphate (Kerr et al. 1949; cf. Mills, 1948).

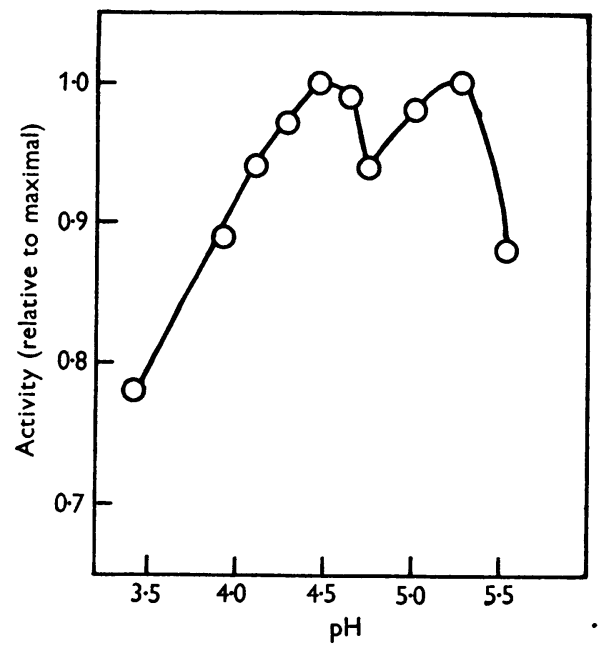

Fig. 7. pH-Activity curve for the insoluble glucuronidase fraction in mouse liver. Unbuffered homogenate freed from inactive material by centrifuging; active material precipitated with acetate buffer, pH 5.2, washed on centrifuge and disintegrated by shaking with Ballotini.

As shown in the next peper in this series (Walker \& Levvy, 1950), the granular material obtained from water homogenates of mouse liver can be disintegrated by shaking at a high speed with Ballotini, Grade 12 (Chance Bros Ltd), without inactivation of glucuronidase. By this method, the enzyme in the granules can be brought into solution, presumably without chemical change. As can be seen from Fig. 7, the resulting preparation gave a $\mathrm{pH}$-activity curve for the hydrolysis of phenolphthalein glucuronide in acetate buffer with peaks at $\mathrm{pH} 4.5$ and 5.2. Preparations of the soluble enzyme from unincubated homogenates gave similar curves. It is evident that the fractionation of the enzyme brought about by centrifuging at $\mathrm{pH} 5.2$ does not coincide with that obtained after partial precipitation with ammonium sulphate.

\section{The action of saccharate}

Suspensions of washed mouse-liver debris in acetate buffer were almost completely inhibited by $10^{-2} \mathrm{M}$-saccharate (Karunairatnam \& Levvy, 1949). This concentration of saccharate was, however, without effect on the conversion to soluble enzyme in acetate buffer at $37^{\circ}$ and $\mathrm{pH} 5 \cdot 2$. After $2 \mathrm{hr}$. incubation in presence of saccharate, the residual activity (42\% of initial) of the washed debris was the same as in controls incubated in absence of saccharate. The soluble enzyme formed was freed from saccharate by twofold precipitation with equal volumes of saturated ammonium sulphate solution (cf. Karunairatnam \& Levvy, 1949). The final activity was once again the same as in the controls (59\% of the initial debris activity).

\section{Fractionation of the enzyme in kidney and uterus}

Table 5 shows the fractionation of the enzyme in mouse kidney and uterus obtained by centrifuging the unincubated water homogenates in acetate buffer, pH 5.2, at $1500 \mathrm{~g}$. The tissue concentration at this stage was $10 \%$ with kidney and $2 \%$ with uterus. After suitable dilution of the two fractions, the assay was carried out in acetate buffer at $\mathrm{pH} 5 \cdot 2$ for kidney and 4.5 for uterus (cf. Kerr et al. 1949). In kidney, as in liver, the higher glucuronidase activity of the infant tissue as compared with adult (Levvy et al. 1948) is seen to be confined to that fraction of the enzyme which was initially soluble. As regards the debris enzyme, the difference between the average figures for infant and adult kidney was not statistic-

Table 5. Fractionation of the enzyme in mouse kidney and uterus in $0 \cdot 1 \mathrm{~N}$-acetate buffer, $\mathrm{pH} 5 \cdot 2$

(Substrate, phenolphthalein glucuronide. Values shown as mean \pm s.e., followed in parentheses by the number of experiments. a.v., glucuronidase units; for definition see text.)

Description of tissue

Kidney, $†$ normal adult

Kdney, $\uparrow 5$ days old

Uterus, $\ddagger$ ovariectomized adult

Uterus, $¥ 4$ days after subcutaneous injection of

$1.7 \mathrm{mg}$. oestrone/kg. in ovariectomized adult
+ Assay at pH 5.2.
Glucuronidase activity (G.U./g. tissue)

$\begin{array}{cc}\text { Supernatant } & \text { Debris* } \\ 1510 \pm 90(6) & 1350 \pm 90(6) \\ 2850 \pm 270(3) & 1090 \pm 140(3) \\ 920 \pm 40(5) & 370 \pm 30(5) \\ 2130 \pm 120(6) & 390 \pm 30(6)\end{array}$

$\ddagger$ Assay at pH 4.5. 
ally significant $(P>0.05)$. In the adult organ, this fraction of the enzyme accounted for nearly $50 \%$ of the total activity. Uterus also contained an insoluble glucuronidase fraction which did not vary with the state of proliferation of the tissue (Table 5). The rise in uterine glucuronidase activity which follows the injection of ovariectomized mice with oestrone (Kerr et al. 1949) was confined to the supernatant.

\section{DISCUSSION}

No evidence from the present investigation causes us to modify our view that the $\beta$-glucuronidase activity of a tissue reflects its state of proliferation (Levvy et al. 1948; Kerr et al. 1949, 1950). It now appears, however, that only a fraction of the enzyme, accounting with normal mouse liver and kidney for slightly more than half the total activity, varies in this respect. The existence of the other insoluble fraction introduces complications into the assay that make it difficult to compare results obtained by different methods. The procedure used by Talalay et al. (1946) in preparing the enzyme for assay leads to the discard of an amount which varies with the period of incubation of the homogenate in the acetate buffer. This may explain some of the difficulties encountered by Mills et al. (1949) in attempting to repeat some of our earlier work, since they incubated the homogenate in acetate buffer, $\mathrm{pH} \mathrm{5, \text {for }}$ $2 \mathrm{hr}$. or more, depending upon the volume, and then discarded insoluble material (Mills, private communication). It is possible that the greater part of the enzyme activity initially present in the granules was obtained in the final extract, but inclusion of this fraction in the activity figures makes differences between normal adult and actively proliferating tissues smaller. Moreover, the autolytic process for release of debris enzyme is limited by heat inactivation and may be affected by other, unknown variables. It should, however, be made clear that the experiments in question were confined to rats (Mills, private communication). The most suitable procedure for following changes in the glucuronidase activity of a tissue in vivo would appear to be the use of the supernatant obtained by centrifuging an unincubated homogenate in acetate buffer, pH 5.2.

Provided. that the $\mathrm{pH}$ and concentration are strictly controlled the use of citrate buffer as in the procedure of Kerr et al. (1948) gives activity figures representing the soluble glucuronidase fraction, even after the homogenate has been incubated for short periods. This buffer has, however, the disadvantage that slight alterations in $\mathrm{pH}$ lead to extraction of the debris enzyme. It should be pointed out that the detailed assay procedure of Kerr et al. (1948), in which concentrated citrate buffer, $\mathrm{pH} 5 \cdot 2$, is added to the homogenate, frequently results in a final $\mathrm{pH}$ of
5.3-5.4. Fortunately, it has been our practice in studying changes in glucuronidase activity to check the $\mathrm{pH}$ of the buffered homogenate, and if necessary adjust it to $5 \cdot 2$ before incubating and centrifuging. Another feature of the assay procedure of Kerr et al. (1948) is the assumption that the activity in a centrifuged homogenate is evenly distributed between precipitate and supernatant before decanting, so that a sample of the latter may be taken as representative of the whole. We have found that this is only true in so far as it refers to that fraction of the tota] enzyme which is soluble at the $\mathrm{pH}$ of the citrate buffer.

In the Discussion to an earlier paper (Kerr et al. 1950), mention was made of preliminary findings in the present investigation, and it was suggested that the active insoluble material contains a precursor of the enzyme. This view was based on experiments with phenol glucuronide as substrate, which showed an increase in the total activity of the homogenate as more enzyme was released from the granular material. For reasons already discussed, the phenol glucuronide method is unreliable when applied to preparations containing insoluble enzyme. More recent experiments leave us no reason to suppose that its insolubility makes this glucuronidase fraction any the less active in the living tissue. Indeed, if the granules are, as we suspect, mainly mitochondria, their glucuronidase activity can be demonstrated in the intact cell by histochemical methods (Campbell, 1949). Bernfeld \& Fishman (1950) have observed activation of glucuronidase by deoxyribonucleate, and suggest that this largely determines the activity of the enzyme in a tissue. On this view, there is no need to imagine the existence of preformed enzyme in an inactive state to explain the increase in the glucuronidase activity of a tissue during active proliferation.

\section{SUMMARY}

1. Addition of acetate buffer, $\mathrm{pH} 5 \cdot 2$, to water homogenates of mouse liver, kidney and uterus causes agglutination of granular material which can then be separated by centrifuging at low speeds. This material has glucuronidase activity, amounting with normal adult liver and kidney to slightly less than half the total in the homogenate.

2. Citrate buffer causes identical fractionation of the enzyme in homogenates, provided that the $\mathrm{pH}$ and concentration are strictly controlled. Increasing the $\mathrm{pH}$ beyond $5 \cdot 2$ or the concentration beyond $0.1 \mathrm{~N}$ leads to extraction of the enzyme in the granules by citrate.

3. Changes in the glucuronidase activity of a tissue in vivo are confined to that fraction of the enzyme which is soluble in acidified water homogenates. 
4. Incubation of homogenates in acetate buffer leads to a progressive release of enzyme from the granules to the solution. This does not occur in citrate buffer.

5. In concentrated homogenates, the presence of the insoluble enzyme fraction can lead to false results for the total activity.

6. The pH-activity curves for the hydrolysis of phenolphthalein glucuronide in acetate buffer by the soluble and insoluble fractions are identical in having peaks at $\mathrm{pH} 4.5$ and $5 \cdot 2$.

7. Saccharate inhibits the enzyme in the granules without affecting its release to the solution on incubation in acetate buffer.

8. The significance of these findings in the assay of glucuronidase is discussed, with particular reference to tissues in varying states of proliferation.

\title{
REFERENCES
}

Becker, B. \& Friedenwald, J. S. (1949). Arch. Biochem. 22, 101.

Bernfeld, P. \& Fishman, W. H. (1950). Fed. Proc. 9, 150.

Campbell, J. G. (1949). Brit. J. exp. Path. 30, 548.

Karunairatnam, M. C. \& Levvy, G. A. (1949). Biochem. J. 44, 599.

Kerr, L. M. H., Campbell, J. G. \& Levvy, G. A. (1949). Biochem. J. 44, 487.

Kerr, L. M. H., Campbell, J. G. \& Levvy, G. A. (1950). Biochem. J. 46, 278.

Kerr, L. M. H., Graham, A. F. \& Levvy, G. A. (1948). Biochem. J. 42, 191.
Levvy, G. A., Kerr, L. M. H. \& Campbell, J. G. (1948). Biochem. J. 42, 462.

Mills, G. T. (1948). Biochem. J. 43, 125.

Mills, G. T. \& Paul, J. (1949). Biochem. J. 44, xxxiv.

Mills, G. T., Paul, J. \& Smith, E. E. B. (1949). 1st Int. Congr. Biochem. Abstr. p. 597.

Morrow, A. G., Greenspan, E. M. \& Carroll, D. M. (1949). $J$. nat. Cancer Inst. 10, 657.

Oshima, G. (1936). J. Biochem., Tokyo, 23, 305.

Talalay, P., Fishman, W. H. \& Huggins, C. (1946). J. biol. Chem. 166, 757.

Walker, P. G. \& Levvy, G. A. (1950). (In preparation.)

\section{The Micro-estimation of Benzoic and Hippuric Acids in Biological Material}

\author{
By F. DICKENS AND JOAN PEARSON \\ Courtauld Institute of Biochemistry, Middlesex Hospital Medical School, London, W. 1
}

\author{
(Received 17 July 1950)
}

In a study of the aromatization of cyclohexanecarboxylic acid and related compounds by animal tissues (Beer, Dickens \& Pearson, 1950) it was necessary to be able to estimate small amounts of benzoic or hippuric acids in presence of other organic acids, and particularly of the unaromatized substrate employed. For this purpose existing methods were not applicable, and in this paper a method is described which has been found adequate for the conditions of the above experiments. The method is based on the nitration of benzoic acid at room temperature, reduction of the resulting mononitrobenzoic acid to aminobenzoic acid, diazotization of the latter and coupling with a colour-forming base. The estimation is completed by colorimetric estimation of the resulting dye and is here described for application to samples containing $0.05-10 \mathrm{mg}$. benzoic acid or equivalent amounts of hippuric acid.

\section{Older methods of estimation of benzoic and hippuric acids}

Urinary hippuric acid has been estimated by isolation and weighing (Friedmann, 1911); a method only suitable for large quantities. The titrimetric procedures of Folin \& Flanders (1912) and Kingsbury \& Swanson (1921) required continuous extraction of the urine with ether and titration of the benzoic acid liberated on hydrolysis of the hippuric acid. Quick (1926) determined instead the amino nitrogen by formol titration. Griffith (1926; see also Hawk \& Bergeim, 1938) destroyed traces of urea in the ether extract and then estimated hippuric acid nitrogen by Kjeldahl analysis. None of these methods is suitable for the present purpose, and the latter two methods cannot be used for estimation of benzoic acid in any case.

Colorimetric methods depending on aromatic structure would obviously be preferable. Nicholls (1928) oxidized benzoic acid by hydrogen peroxide to salicylic acid which can be colorimetrically estimated; this oxidation proceeds only to the extent of about $10 \%$, and is therefore an unsatisfactory basis for a quantitative method.

The most promising published micromethod for benzoic acid estimation appeared to be that of Waelsch \& Klepetar (1935) and Waelsch \& Busztin (1937). This is based on the hot nitration of benzoic acid to give a dinitrobenzoic acid, thought (Mohler, 